\title{
IoT-Based Technological Innovation in Improving the Productivity of Macan Kumbang Fish Cultivator
}

\author{
Nelly Masnila ${ }^{1}$, Indra Griha Tofik $\operatorname{Isa}^{2}$, Hendradinata Hendradinata ${ }^{3, *}$, \\ Riana Mayasari ${ }^{4}$ \\ ${ }^{1,4}$ Accounting Department, Politeknik Negeri Sriwijaya \\ ${ }^{2}$ Informatics Management Department, Politeknik Negeri Sriwijaya \\ ${ }^{3}$ Mechanical Engineering Department, Politeknik Negeri Sriwijaya \\ ${ }^{*}$ Corresponding author. Email: indra_isa_mi@polsri.ac.id
}

\begin{abstract}
The fishery sector is one of the main commodities in South Sumatra because fish consumption in South Sumatra is relatively high due to the many processed snacks made with fish. Based on BPS data, fish commodity is one of the contributors to $0.27 \%$ of increasing inflation in South Sumatra. This is an opportunity also a challenge for all stakeholders in an effort to fulfill the market needs especially in fishery sector to reduce the inflation rate, including the readiness of fish cultivators to increase the effectiveness of fishery production. One of the fish cultivators in South Sumatra is the "Macan Kumbang" Fish Cultivator Group that located in Palembang. Based on initial observations, the problems were irregular feeding, unmeasured water quality, has not utilizing fish waste and has not measuring the prediction return on investment. This group has a strong desire to carry out cultivation using IoT-based technology. The objectives of the study is to find out how much IoT technology is applied in fish farming and find out the problems and opportunities to produce Applied Technology (TTG) in fish farming with IoT technology. Research Method using prototyping methodology and system development life cycle in software development aspect. The limitation of technology developed integrates microcontroller and sensor with 3 subsystems, those are: (1) Automatic fish feeding, (2) Quality Control and Water Drainage, (3) Prediction of Return on Investment. The data read by the sensor is uploaded into a cloud database that can be accessed via a gadget, so that users can directly control feeding, see water quality and predict returns on investment. The stages of system development are divided into 2 aspects, namely Software Development and Microcontroler Hardware Development. The results of the implementation of the tool for fish cultivators found an increase in production output of $45 \%$ with an average effectiveness in terms of costs and production yields with an average value of $25 \%$
\end{abstract}

Keywords: Fish Cultivator, IoT-Based Technology, Fishery Sector

\section{INTRODUCTION}

\subsection{Introduction}

Fish is one of the main commodities in Palembang because most of Palembang's typical snacks are made from fish [1] such as pempek, tekwan, model, pindang and others. So from this potential, it becomes a challenge, especially fish cultivators in providing sufficient fish raw materials to meet the needs of the Palembang market. Based on data from the Central Bureau of Statistics (BPS) of South Sumatera in 2021, the overall production of fish farming (including cultivation) in South Sumatera is 439,059 tons [2].
It has been noted that in 2008, based on data from the Central Bureau of Statistics, it illustrates that there has been an increasing in inflation of $0.27 \%$ in South Sumatera with Palembang's inflation rate of $0.26 \%$ and Lubuk Linggau's $0.39 \%$ [3]. Several aspects that contributed to the inflation growth rate, one of those factor was the fishery sector.

As an effort by the government in suppressing the inflation growth rate in South Sumatera caused by the decreasing in fish production, it is carried out by intensifying fish cultivation, both consumption fish and ornamental fish [4]. Especially in Palembang, based on data from the Central Bureau of Statistics that the total 
aquaculture households in 2020 amounted to 5,167 cultivators, this is a significant increasing where previously in 2018 there were 1050 cultivators [5].

One of the fish cultivator groups in Palembang is "Macan Kumbang" Fish Cultivator Group which cultivates various kinds of fish such as catfish, silver catfish, tilapia, carp fish and other consumption fish. This group was formed in 2005 with 10 cultivators as initial members, then has grown up until now, and has about 30 cultivators. Based on the observations and interviews, this fish cultivators group needs innovation in increasing the productivity of fishery products that is integrated with the Internet of Things (IoT).

In the research that be carried out, it will integrate IoT into a fish cultivator controller. This IoT-based technology has several capabilities needed by fish cultivators. The first is an automatic fish feeder with water ripple reading through sensors that trigger the fish feeder mechanic automation, so that it can provide feed when the fish are hungry. Second, this technology can provide information about water conditions with various parameters including water acidity conditions or $\mathrm{pH}$, water temperature conditions, water turbidity conditions and water meter level conditions. In the user interface, besides being able to see the condition of the water, it can also facilitate the user to drain the water where the controller turn on the pump and then distributed the water into hydroponic fermenter which is integrated with the system. Third, there is a facility for calculating the return on working capital for cultivation by applying the calculation of Net Present Value (NPV) and Payback Period (PP) approach method through several aspects, those are Total Cultivation Costs, Cultivation Duration and Total Income.

\subsection{Formulation of The Problem}

Based on the description of the introduction above, the formulation of the problem from this research is:

1. How is IoT used in the fish cultivation process in "Macan Kumbang" Fish Cultivator Group?

2. What are the supporting and obstacle factors in the process of fish cultivation in the "Macan Kumbang" Fish Cultivator Group?

\subsection{Research Objective}

Based on the formulation of the problem above, the specific objective of the study are:

1. Knowing how much IoT based Technology is used in fish cultivation;

2. Knowing the problems and opportunities to produce the Applied Technology (TTG) in fish cultivation with IoT. The applied TTG is expected to be able to analyze profit projections, automatic feeding, detect fish appetite, measure water quality and utilize aquaculture waste/by-products to reduce operational costs.

\subsection{Urgency of Research}

The urgency of this research is the need for fish cultivation automation. Technology must be able to calculate the return on investment, simulate costs, measure water quality, automatically feed, detect fish hungry, use fish waste as liquid fertilizer and can be controlled using the internet in Android and Web applications.

\section{LITERATURE REVIEW}

\subsection{Previous Research}

Research conducted by Supriadi and Putra [6] related to the Internet of Things-based Automatic Fish Feeder Scheduling and Monitoring System where the control system was built with fish feeding tools, namely the Design and Build of IoT based Automatic Fish Feeder Monitoring and Scheduling System. So that when feeding this can be adjusted to the number and age of fish to be more efficient in the dose and duration of feeding fish. What's more, fish farmers can save on feed to do work and produce quality fish.

Another study developed a tool that serves to help monitor and control the water quality of catfish ponds based on the Internet of Things. The equipment needed is an acidity $(\mathrm{pH})$ sensor, a temperature sensor and a relay to regulate the water oxygen aerator. Data from these sensors is recorded by the Raspberry Pi and then processed into information according to user needs through internet automatically. Furthermore, the data can be displayed on various platforms, one of which is the mobile web model [7].

Meanwhile, in the other research developing a fish cultivator tool with the ADXL335 accelerometer sensor which functions to determine whether the fish are still hungry or already full by using three parameters, namely the $\mathrm{x}, \mathrm{y}$ and $\mathrm{z}$ axis, this axis is used to determine the value of the fish cultivator. reference and values obtained for each axis $\mathrm{x}=329,330,331$, y axis $=339$, 340,341 and $\mathrm{z}$ axis $=349,350,351$. Meanwhile, to determine the amount of feed depleted, a load cell sensor is used, the output of the load cell will be sent to the smartphone using the Blynk application and a message will be displayed that the feed is almost exhausted if the weight of the feed reads is 50 grams and below. This monitoring system has been connected to the NodeMCU ESP8266 module as IoT so that it can be monitored remotely [8]

This research is intended to handle the problems in fish cultivation activities that were previously still done conventionally by using Internet of Things (IoT)-based media that can be accessed through gadgets. In addition, 
the fish cultivation system is integrated through in a comprehensive automation of tools and the use of fish waste as hydroponic liquid fertilizer with the support of android-based IoT. Because generally automatic fish feeders are only able to automatically feeding fish as scheduled, have not been able to calculate return of investment using NPV and PP approach, have not been able to detect fish conditions, have not been able to measure water quality and have not utilized fish cultivation waste to reduce operational costs in an integrated system with IoT .

\subsection{Net Present Value and Payback Period}

Net Present Value or NPV is the difference between the value of cash inflows with the value of cash outflows over a period of time. According to economics, Net Present Value is an estimate of future cash flows minus current discounts using the social opportunity cost of capital [9].

The net present value (NPV) criterion is based on the concept of discounting all cash flows to their present value. By discounting all cash inflows and cash outflows over the life of the project (investment) to their present value, then calculating the net present value using the same basis, which is the current price. Thus, the criteria for assessing NPV focused on two things at once, these are the time value of money and the difference in the amount of cash inflows and outflows [10].

In other words, NPV can show the amount (lumpsum) with a certain discount and give how much money in present time [10]. In the cash flow of the certain investment project, to calculate the NPV to be studied, it covers all aspects of cash receipts and all aspects of cash out, which are mathematically formulated as follows:

$$
N P V=\sum_{t=0}^{n} \frac{(C) t}{(1+i)^{t}}-\sum_{t=0}^{n} \frac{(C o) t}{(1+i)^{t}}
$$

Description :

$$
\begin{array}{ll}
\mathrm{NPV} & =\text { Net Present Value; } \\
(\mathrm{C}) \mathrm{t} & =\text { Cash inflows year } \mathrm{t} ; \\
(\mathrm{Co}) \mathrm{t} & =\text { Cash outflows year } \mathrm{t} ; \\
\mathrm{n} & =\text { investment duration (year); } \\
\mathrm{i} & =\text { Rate of Return (ROR); } \\
\mathrm{t} & =\text { year. }
\end{array}
$$

\subsection{Microcontroler}

A microcontroller is a complete microprocessor system contained within a chip. Microcontroller is different from the general purpose microprocessor used in a PC, because a microcontroller generally already contains a minimum system support component of a microprocessor, namely memory and input-output programming [11]. Microcontrollers are usually in the form of IC chips where there is a microprocessor and ROM program memory (Read Only Memory) as well as general-purpose memory RAM (Random Access Memory), there are even several types of microcontrollers that have ADC, PLL, EEPROM feature in one package.

\subsection{Turbidity Sensor}

Turbidity sensor that can detect the turbidity of water by reading the optical properties of water due to light and as a comparison of the light to be reflected with the incoming light. Turbidity is a condition of water that is not clear and is caused by individual particles (suspended solids) which are generally invisible to the eye, similar to smoke in air. The more particles in the water, the higher the turbidity of the water. On the turbidity sensor, that the higher the level of water turbidity will be followed by the changing in the sensor output voltage [12].

\subsection{Sensor HCSR-04}

The HCSR-04 sensor is an ultrasonic wave-based distance measuring sensor. The advantage of this sensor is the detection range of about $2 \mathrm{~cm}$ to the range of 400 $500 \mathrm{~cm}$ with a resolution of $1 \mathrm{~cm}$. The HCSR-04 sensor is a low cost version of the ultrasonic PING sensor made by parallax. The difference lies in the pins used. HCSR-04 uses 4 pins while PING made by Parallax uses 3 pins [13].

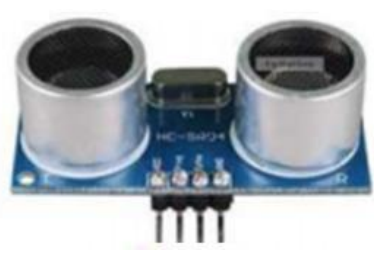

Figure 1. Ultrasonic Sensor a.k.a HCSR-04

\subsection{Sensor pH E-201-C}

The basic principle of measuring $\mathrm{pH}$ using $\mathrm{pH}$ meter is the electrochemical potential that occurs between the known solution inside the glass electrode and the unknown solution outside the glass electrode. This is because a thin layer of glass bubbles will interact with hydrogen ions which are relatively small and active [14].

The $\mathrm{pH}$ meter electrode scheme will measure the potensial of electric between mercury chloride $(\mathrm{HgCl})$ at the reference measure electrode and potassium chloride $(\mathrm{KCl})$ which is a solution in the electrode glass as well 
as the potential between the solution and the silver electrode. But the potential between the unknown sample and the glass electrode can change according to the sample.

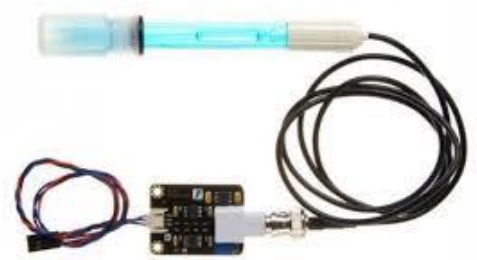

Figure 2. Sensor pH E-201-C

\subsection{Temperature Sensor DS18B20}

DS18B20 or temperature sensor is a temperature sensor that uses a one-wire interface, so it only uses a few wires in its installation. Uniquely, this sensor can be used in parallel with one input. This means that we can use more than one DS18B20 sensor but the sensor output is only connected to one Arduino pin. This reason makes this sensor widely used, especially since this sensor has a waterproof type, so this sensor can be made as a measuring and controlling tool for water heaters [15].

\subsection{Internet of Things (IoT)}

The IoT concept is actually simple with the way it works referring to 3 main elements in the IoT architecture, these are : (1) Physical Goods equipped with IoT modules, (2) Connection Devices to the Internet such as Modems and Speedy Wireless Routers, and (3) Cloud Data Center where application being stored including its databases.

The basic working principle of IoT devices is that objects in the real world are given a unique identity and can be multiplied in a computer system and can be represented in the form of data in a computer system. At the beginning of the implementation of the idea of IoT, the identifier used so that objects can be identified and read by a computer is to use a barcode, Quick Response Code (QR Code) and Radio Frequency Identification (RFID). In its development an object can be given an identifier in the form of an IP address and use the internet network to be able to communicate with other objects that have an IP address identifier [16].

\section{METHOD}

The research involves protoyping methodology approaching which adapted to control system development. The stage initiated by collecting data and information needed to the study by using qualitative analysis, designing prototype, evaluating prototype, coding system, testing system, result and conclusion [17].

\subsection{Research Subject and Object}

The research subjects consist of 2 entities that are related to the system, consisting of (1) fish cultivators of Macan Kumbang and (2) Fish Cultivator Organizations of Macan Kumbang. While the object of research is fish cultivation automation tool that is integrated with the use of fish waste as liquid fertilizer for hydroponic plants as well as prediction of return on investment with the NPV - PP approach.

\subsection{System Development Method}

System Development is divided into software and microcontroller or hardware system. The stages of software development refer to the system development life cycle (SDLC) which consists of:

1. System Analysis, that carried out by deepening of the problems and research objects that produce the Proposed System to be built;

2. System Design by modeling context diagrams and compiling data flow diagrams regarding the three aspects built into the system consisting of automatic feeding, water quality control and prediction of return on investment with NPV-PP approach

3. Coding process for microcontrollers and applications and integration with cloud databases

4. Blackbox Testing System Testing by giving test scenarios to the system carried out by the user testing

While the stages of microcontroler hardware development are:

1. Create a block diagram and flow chart of 3 subsystems;

2. Development of automatic feed system integrated with fish hungry's detection sensor;

3. Development of a Water Quality Controller circuit by integrating $\mathrm{pH}$ sensors, temperature sensors, turbidity sensors and water level sensors;

4. Development of Fish Waste Treatment Automation Mechanics through water drain shippers;

5. Testing the circuit to see the sensitivity of the sensor and the automatic mechanics of the shipper of water drain. 


\subsection{Data Collection Technique}

There are 3 kinds of data collection technique, they are:

1. Observations that carried out by observing the subject of research and looking at the current system that is running, especially in the aspect of fish cultivation

2. Literature study by reviewing theories that are relevant to the aspects of the problem being studied

3. Interviews were conducted in a semi-structured method through the selection of purposive sampling informants with a face/expert analysis approach, they are Fish Cultivator of Macan Kumbang and the Cultivator Organization of Macan Kumbang.

\subsection{Data Analysis}

Prior to data analysis, the validity of the data was tested with credibility test through the following technique [18]:

1. Triangulation, is a multi-method approach in data collection and analysis. Triangulation used triangulation of time, technique, and source

2. Member Check, is a technique to confirm the suitability of the interpretation of data from interviews with informants.

3. Analysis of negative cases, is a search for data that is different or contradicts the data that has been found.

In this study, data analysis was carried out by thematic analysis which is part of a qualitative analysis that aims to identify, analyze, and report patterns in the data and present them in detail and complete [19].

Data analysis in this study used thematic analysis. which is a qualitative research analysis technique to identify, analyze, report patterns in the data and present them in detail and complete. In addition, data collection and analysis also aims to measure the quality of fish cultivation automation tools that are integrated with the use of fish waste as liquid fertilizer for hydroponic plants as well as return of investment prediction using the NPV - PP approach.

\section{RESULT AND DISCUSSION}

\subsection{System Analysis}

System analysis is carried out by observing at the current system and providing an overview of how the proposed system will be built. After defining the current system, then designing proposed system. Figure 3 below is a design of the proposed system that to be built:

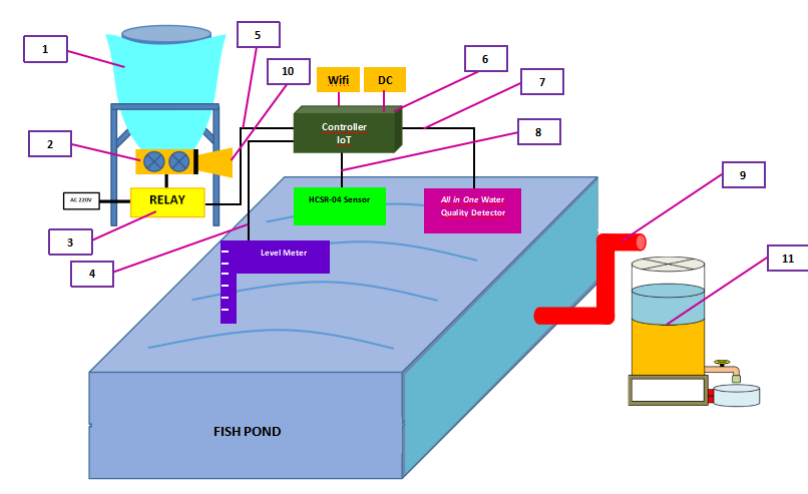

Figure 3. Proposed System Workflow

Description:

1. Fish feed storage container

2. Fish feeding blower

3. Relay as automatic switch for feeding fish

4. Parameter line from water meter level sensor to IoT controller

5. Parameter line turns on automatic relay based on input from fish movement detector

6. IoT controller as a water meter level sensor controller, fish hungry's detector, water quality detector connected to the internet network and cloud database. The output of the IoT controller can be displayed in an Android-based Gadget.

7. Parameter line of the all in one Water Quality Detector, which consists of a $\mathrm{pH}$ sensor, a water turbidity sensor, a temperature sensor

8. Fish hungry's detector parameter line based on fish movement

9. Shipon pipe for draining of fish waste sediment

10. Fish feeding funnel

11. Liquid Fermenter for Hydroponics

\subsection{System Design}

In System Design, it is carried out by providing several technical descriptions of the system to be built, which includes Context Diagrams, Data Flow Diagrams, Block Diagrams, and Flowcharts.

\subsubsection{Context Diagram}

The context diagram in Figure 4 shows 2 entities that interact with the system, including fish cultivators and fish cultivator organizations. Fish cultivators have relations from and to the system, while fish cultivator organizations only have relations from the system: 


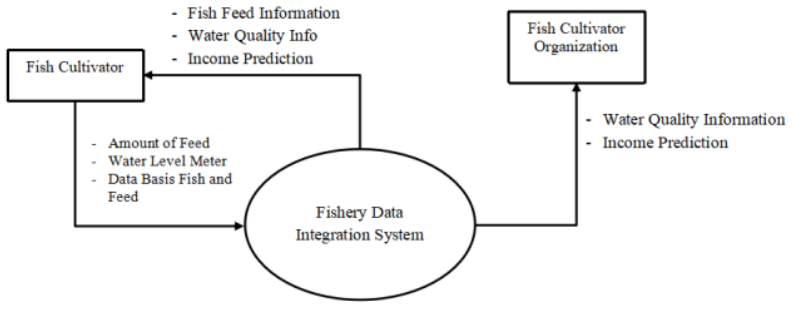

Figure 4. Context Diagram

\subsubsection{Data Flow Diagram}

The data flow diagram is a more detailed description of the context diagram that made previously. In the data flow diagram there are several processes related to the system, which consist of login, fish feeding, quality control and water drain, Return of Investment Prediction. There are 8 parts of storage data, they are dt_user, dt_pakan,dt_riak, dt_temperature, dt_level_air, dt_ph, dt_kekeruhan and dt_prediction. Each process has a relation to data storage, as shown in table 1:

Table 1. The Relation among Process and Storage Data

\begin{tabular}{|c|l|l|}
\hline No & \multicolumn{1}{|c|}{ Process } & \multicolumn{1}{c|}{ Data Storage } \\
\hline 1 & Login & $\mathrm{dt}$.user \\
\hline 2 & Fish Feeding & $\mathrm{dt}$ _pakan,dt_riak \\
\hline 3 & $\begin{array}{l}\text { Quality Control and } \\
\text { Water Draian }\end{array}$ & $\begin{array}{l}\mathrm{dt} \text { ttemperature, } \\
\text { dt_riak, dt_kekeruhan, } \\
\text { dt_level_air }\end{array}$ \\
\hline 4 & Income Prediction & dt_prediksi \\
\hline
\end{tabular}

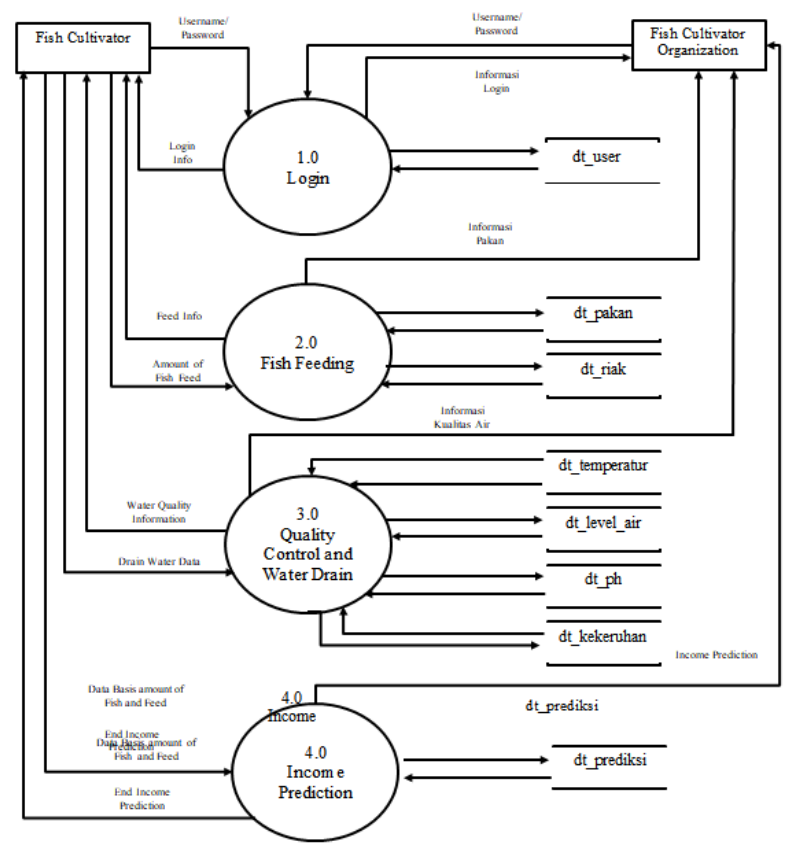

Figure 5. Data Flow Diagram

\subsubsection{Block Diagram}

As a representation of the software and microcontroller devices used, it is illustrated with a Block Diagram as shown in Figure 6 where there are 3 main parts, those are automation mechanics and controllers, databases that are accessed through cloud data and user interfaces that make it easy for users to interact with the system.

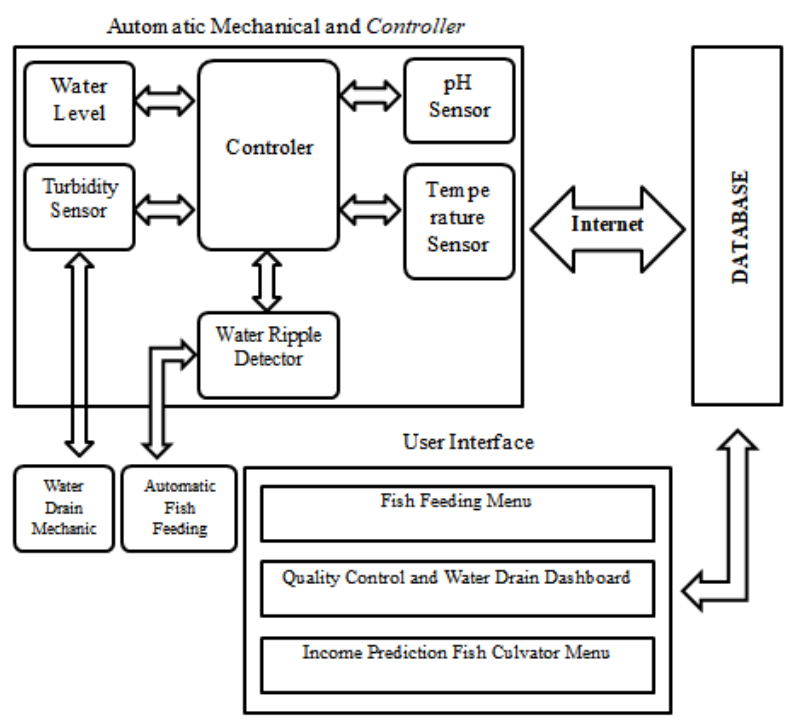

Figure 6. Block Diagram

From that 3 main blocks, which consist of (1) Automatic Mechanics and Controller, (2) Cloud database and (3) User Interface. Sensors contained in automatic mechanics and controllers take readings data of the environment, including water levels, turbidity, $\mathrm{pH}$ sensors, temperature sensors and water ripple detectors. The reading data is stored in a cloud database through the internet network, which is then represented to the user through a user interface display consisting of (1) Fish Feeding Menu, (2) Water Quality and Drainage Control Dashboard and (3) Return of Investment Prediction Menu of Fish Cultivator. The user interface can provide triggers or feedback to the automatic mechanics for automatic and manual fish feeding and draining mechanics. 


\subsubsection{Flowchart}

Here is the flowchart figure from the system that to be built :

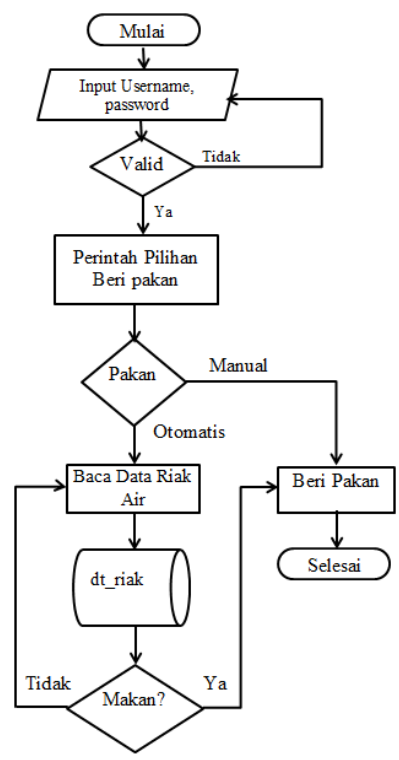

Figure 7. Flowchart Fish Feeding

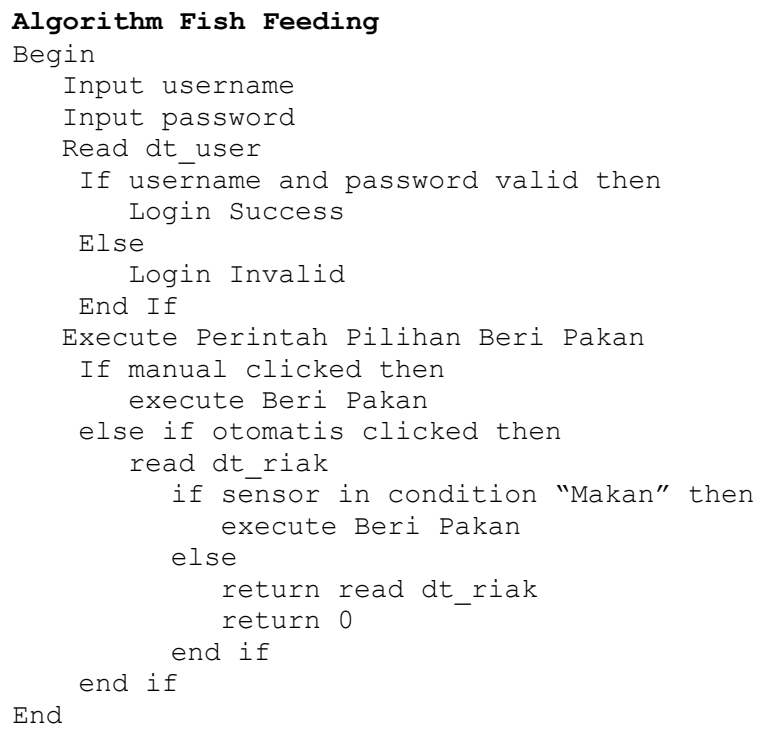

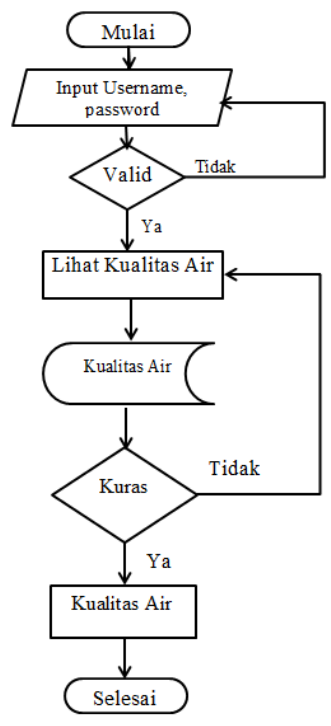

Figure 8. Flowchart Quality and Water Drain

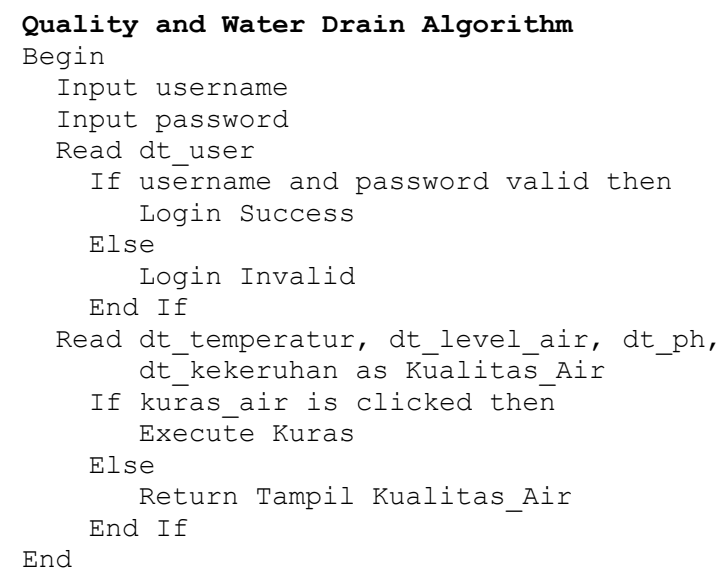

\subsection{System Implementation}

\subsubsection{User Interface}

Figure 9 shows the user interface, the login menu and the main menu, which consists of 4 buttons, namely "Beri Pakan", "Kontrol Air", "Prediksi Pendapatan" and "Logout". The button in the main menu will direct to the Menu of Fish Feeding, Quality Control and Water Drain and Return of Investment Prediction Menu 

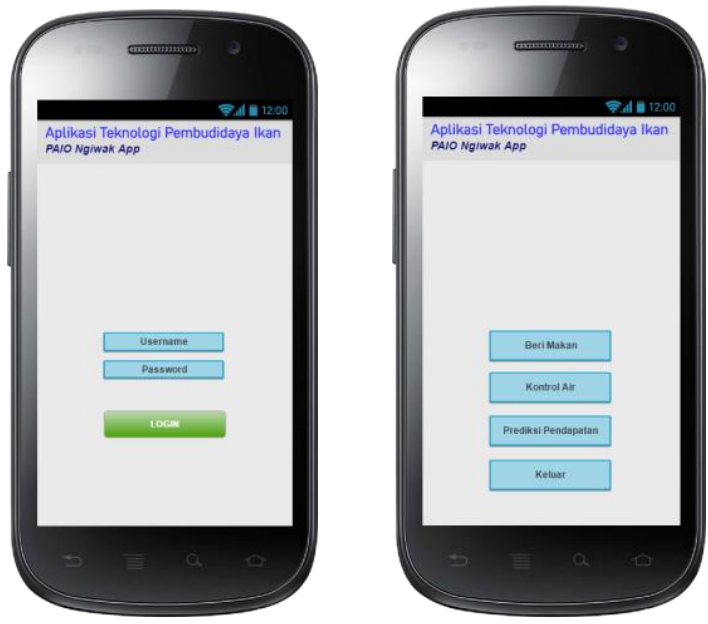

Figure 9. User Interface Login and Main Menu

In Figure 10 terdapat menu pemberian pakan ikan yang didalamya terdapat fasilitas pemberian pakan ikan secara otomatis maupun manual serta Dashboard Kontrol Kualitas dan Kuras Air, didalamnya terdapat kondisi air yang meliputi kondisi kadar $\mathrm{pH}$ air, kondisi kekeruhan air, kondisi suhu atau temperatur air dan kondisi level meter air. Selain kondisi air, di dalam Dashboard ini dilengkapi dengan fasilitas kuras air

In Figure 10 there is a fish feeding menu which includes automatic or manual fish feeding facilities and Water Quality and Drainage Control Dashboard, in which there are water conditions which include water $\mathrm{pH}$ levels, water turbidity conditions, temperature conditions or water temperature and level conditions. water meters. In addition to water conditions, the Dashboard is equipped with draining facilities;
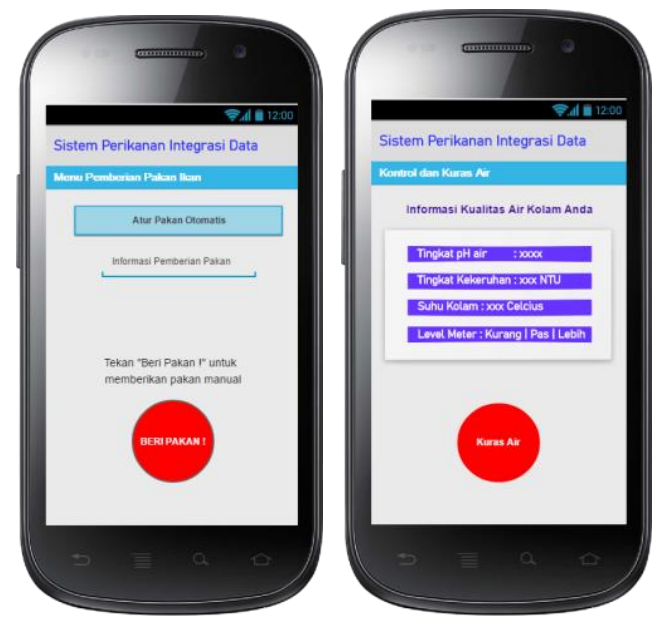

Figure 10. Fish Feeding Menu and Quality ControlWater Drainage User Interface

While in figure 11 there are 3 main parts consisting of the duration of cultivation, the total cost of cultivation and income. In the Cultivation Duration, there are inputs for the start date of cultivation and the date the product was sold, the result of difference being the Cultivation Duration. Then in part 2 there are several inputs consisting of feed costs, labor costs, hatchery costs, maintenance costs, overhead costs, utility costs as well as distribution and marketing costs, all of which are summed up to be Total Cultivation Costs. While in the third part there is total income which is the Amount of Harvest multiplied by the Selling Price of the Product.

So that in predicting return of investment through the return of working capital for cultivation, look at these three aspects, those are duration of cultivation, total cost of cultivation, and total income. If translated, the formulation is (Total Cultivation Cost / Total Income) $x$ Cultivation Duration

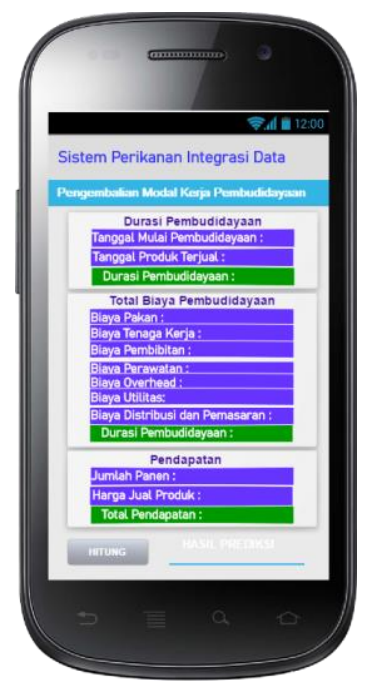

Figure 11. Return of Investment Menu User Interface

\subsubsection{Blackbox Testing}

After the system implementation stage is carried out with the user interface coding process, the next stage is test the system with BlackBox Testing to assess the functional quality of the system. The steps taken are the user is given a test scenario, then the user does the test. If the results obtained are in accordance with the test results, the user will give an assessment of "OK" or a tick $(\mathrm{V})$, but if the results do not match the parameters, the user will write "NOT OK" or a cross $(\mathrm{X})$. The following table 2 shows the results of the Blackbox Testing of the fishery data integration system

Tabel 2. Blackbox Testing Result

\begin{tabular}{|c|l|l|l|c|}
\hline No & \multicolumn{1}{|c|}{ Aspect } & Test Scenario & \multicolumn{1}{|c|}{ Result } & Status \\
\hline 1 & Login & $\begin{array}{l}\text { Login with } \\
\text { valid account }\end{array}$ & $\begin{array}{l}\text { Entry the Main } \\
\text { Menu }\end{array}$ & OK \\
\cline { 3 - 5 } & $\begin{array}{l}\text { Login up } \\
\text { dengan akun } \\
\text { invalid }\end{array}$ & $\begin{array}{l}\text { pop } \\
\text { notification } \\
\text { appears }\end{array}$ & OK \\
\hline 2 & $\begin{array}{l}\text { Fish } \\
\text { Feeding }\end{array}$ & $\begin{array}{l}\text { Unlocking the } \\
\text { Feed Feed Fed }\end{array}$ & OK \\
\hline
\end{tabular}




\begin{tabular}{|c|l|l|l|c|}
\hline No & \multicolumn{1}{|c|}{ Aspect } & Test Scenario & \multicolumn{1}{|c|}{ Result } & Status \\
\hline \multirow{2}{*}{3} & Menu & $\begin{array}{l}\text { Automatic } \\
\text { Feed } \\
\text { Selection }\end{array}$ & $\begin{array}{l}\text { Reading the } \\
\text { water ripple } \\
\text { data }\end{array}$ & OK \\
\hline $\begin{array}{l}\text { Control } \\
\text { and Wality } \\
\text { Drainage }\end{array}$ & $\begin{array}{l}\text { View Water } \\
\text { Parameters }\end{array}$ & $\begin{array}{l}\text { Result of } \\
\text { sensor } \\
\text { parameter } \\
\text { appears }\end{array}$ & OK \\
\cline { 2 - 5 } & $\begin{array}{l}\text { Select Water } \\
\text { Drainage }\end{array}$ & $\begin{array}{l}\text { Turning on the } \\
\text { water pump } \\
\text { using relay }\end{array}$ & OK \\
\hline 4 & $\begin{array}{l}\text { Return of } \\
\text { Investment } \\
\text { Menu }\end{array}$ & Input data & $\begin{array}{l}\text { Input Data } \\
\text { menu is Active }\end{array}$ & OK \\
\cline { 2 - 5 } & $\begin{array}{l}\text { Calculation } \\
\text { the data input }\end{array}$ & $\begin{array}{l}\text { Calculation } \\
\text { Result appears } \\
\text { in prediction } \\
\text { textbox }\end{array}$ & OK \\
& & \multicolumn{2}{|c}{} \\
\hline
\end{tabular}

\subsubsection{Fish Cultivator Controller Testing}

In addition to functional testing related to data integration fishery system software, microcontroller testing was also carried out by observing at several aspects including feed ejection or throwing power, throw capacity per minute, water ripple distance readings, turbidity level readings, temperature readings, $\mathrm{pH}$ level readings. Table 3 shows the results of testing the data integration fisheries system

Table 3. Microcontroler Testing Result

\begin{tabular}{|c|c|c|}
\hline No & Description & Result \\
\hline 1 & Feed Throwing Power & 3-4 Meters \\
\hline 2 & $\begin{array}{l}\text { Throwing Capacity per } \\
\text { Minute }\end{array}$ & 200 gram per menit \\
\hline 3 & $\begin{array}{l}\text { Water Ripple Distance } \\
\text { Reading }\end{array}$ & $\begin{array}{l}\text { In parameter intensity of } 80 \mathrm{~cm} \\
\text { turning on the relay of feed } \\
\text { feeder }\end{array}$ \\
\hline 4 & Read level of turbidity & $\begin{array}{l}\text { turning on the relay of water } \\
\text { pump in certain turbidity of } \\
\text { water }\end{array}$ \\
\hline 5 & $\begin{array}{l}\text { Read level } \\
\text { temperature }\end{array}$ & $\begin{array}{l}\text { Read water temperatur in pond } \\
\text { between } 21-28^{\circ} \mathrm{C}\end{array}$ \\
\hline 6 & Read level of $\mathrm{pH}$ & $\begin{array}{l}\text { Read water } \mathrm{pH} \text { in pond between } \\
6-7 \text { level of } \mathrm{pH}\end{array}$ \\
\hline
\end{tabular}

From the table above, it can be seen that the ejection power of the feed ranges from a distance of 3 to 4 meters. The smaller the diameter of the feed, the farther the ejection power from the feed. In this study, the maximum ejection power was 4 meters with a size of $5 \mathrm{~mm}$ diameter round fish feed. While the capacity of throwing feed in 1 minute is 200 grams with the use of wind media through a blower in the process of throwing feed.

From testing the fish pond water through the sensor device for reading the distance of the water ripple in the parameters distance reading of $80 \mathrm{~cm}$. This water ripple distance reading provides a trigger for the relay to throw feed, if the water ripple is higher, it is assumed that the fish are hungry and the catapult will throw fish feed into the pond. For the turbidity sensor, could turn on the water pump in certain turbidity of water. The reading of the temperature level based on the fish pond water is in the value of $21^{\circ}$ to $28^{\circ} \mathrm{C}$ while the reading of the $\mathrm{pH}$ level is in the value of 6 to 7 .

\subsection{Analysis of Cost Effectiveness and Production Results}

In analyzing the return on investment, it is carried out by interviewing several members of fish cultivators by looking at the financing parameters shown in table 4 . During the 3 weeks of implementing the tool, the percentage value of effectiveness obtained by comparing the conditions before and after the implementation of the tool is obtained.

Table 4. Condition After Cultivator Microcontroler Implemented

\begin{tabular}{|r|l|c|}
\hline No & \multicolumn{1}{|c|}{ Description } & Effectiveness \\
\hline 1 & Feed Cost & $43 \%$ \\
\hline 2 & Labor Cost & $85 \%$ \\
\hline 3 & Utility Cost & $10 \%$ \\
\hline 4 & Maintenance Cost & $-13 \%$ \\
\hline 5 & Overhead Cost & $-5 \%$ \\
\hline 6 & Distribution and Marketing Cost & $12 \%$ \\
\hline 7 & Production Result & $45 \%$ \\
\hline & Average & $\mathbf{2 5 \%}$ \\
\hline
\end{tabular}

Based on the conditions after the implementation of fish cultivator tools, on the average rate there is an increasing in effectiveness from the aspect of financing and production result by $25 \%$ where the effectiveness of labor costs is $85 \%$, which means that labor costs can be reduced to $85 \%$. The lowest value is from the aspect of maintenance costs with a value of $-13 \%$ which means an increase in maintenance costs of $13 \%$ where this increase is due to the need for maintenance costs in the maintenance of fish cultivation equipment. Meanwhile, for production, there was an increase of up to $45 \%$.

\section{CONCLUSION}

Research conducted by utilizing IoT-based technology can increase the productivity of fishery products in the "Macan Kumbang" fish cultivator group. The stages carried out by developing a software and microcontroller system resulted in an average increase in productivity results from the cost and production aspects of $25 \%$ when compared before implementing an IoT-based system in fish cultivation, specifically the increasing of production result is $45 \%$.

Several factors that support the increase in productivity are the accuracy of the sensor and microcontroler devices used in measuring water quality 
in terms of turbidity level, acidity level, water meter level and water ripples as detection of fish in hungry condition. With IoT-based automation, it is easier for fish cultivator to provide fish feeding on time, controlling water drainage if the water level exceeds the turbidity or $\mathrm{pH}$ threshold. The obstacle factor based on the results of the assessment of the effectiveness of the device after the IoT-based system is implemented is the aspect of maintenance costs and overhead costs due to the need for a budget for periodic repairs and maintenance related to the microcontroller equipment used, it is also necessary to consume electrical power in operating the device which is charged to overhead costs.

\section{ACKNOWLEDGMENTS}

The researcher team would like to thank all those who have helped, especially the Center for Research and Community Service (P3M) of the Politeknik Negeri Sriwijaya which provided funding for Riset Terapan Unggulan scheme and to partners of "Macan Kumbang" Fish Cultivation Group who have participated in the running of the research very well.

\section{REFERENCES}

[1] Alhanannasir, Idealastuti, Suyatno, Mukhtarudin, P. M. Sari, and A. V. Yani, "Pelatihan Pengolahan Pempek Berbahan Jamur Tiram Putih Sebagai Pengganti Ikan," Suluh Abdi J. Ilm. Pengabdi. Kpd. Masy., vol. 1, no. 2, pp. 69-74, 2019.

[2] Badan Pusat Statistik Provinsi Sumatera Selatan, Provinsi Sumatera Selatan dalam Angka - Sumatera Selatan Province in Figures 2021. Palembang: BPS Provinsi Sumatera Selatan, 2021.

[3] Badan Pusat Statistik Kota Palembang, Indikator Ekonomi Kota Palembang. Palembang, 2020.

[4] Dinas Perikanan Kota Palembang, "Rencana Kerja Dinas Perikanan Kota Palembang Tahun 2020," Dinas Perikanan Kota Palembang, Palembang, 2020.

[5] Dinas Kelautan dan Perikanan Provinsi Sumatera Selatan, "Total Rumah Tangga Perikanan Budidaya 2021,” Palembang, 2020. [Online]. Available: https://sumsel.bps.go.id/indicator/56/684/1/total -rumah-tangga-perikanan-budidaya.html.

[6] S. Supriadi and S. A. Putra, "Perancangan Sistem Penjadwalan Dan Monitoring Pemberi Pakan Ikan Otomatis Berbasis Internet of
Thing," J. Apl. Dan Inov. Ipteks "Soliditas," vol. 2, no. 1, p. 35, 2019, doi: 10.31328/js.v2i1.1286.

[7] E. Rohadi et al., "Sistem Monitoring Budidaya Ikan Lele Berbasis Internet Of Things Menggunakan Raspberry Pi," J. Teknol. Inf. dan Ilmu Komput., vol. 5, no. 6, p. 745, 2018, doi: 10.25126/jtiik.2018561135.

[8] Marisal and Mulyadi, "Rancang Bangun Alat Pemberi Pakan Ikan Otomatis Berbasis Android," J. ER Sales, vol. 2, no. 1, pp. 51-54, 2020.

[9] D. Purnantiyo, "Analisis Kelayakan Investasi Alat DNA Real Time Thermal Cycler (RTPCR) untuk Pengujian Gelatin," J. PASTI, vol. VIII, no. 2, pp. 212-226, 2015, doi: $10.3109 / 9780203997352.224$.

[10] C. F. K. Sari, M. E. Sawaki, and M. S. Sabarofek, "Pengaruh Analisis Investasi terhadap Kelayakan Penambangan Batu Mangan di PT. Berkat Esa Mining," J. Sci. Tech, vol. 4, no. 1, pp. 11-18, 2018.

[11] A. B. Santoso, Martinus, and Sugiyanto, "Pembuatan Otomasi Pengaturan Kereta Api, Pengereman, dan Palang Pintu pada Rel Kereta Api Mainan berbasis Mikrokontroler," $J$. FEMA, vol. 1, no. 1, pp. 16-23, 2013.

[12] A. Noor, A. Supriyanto, and H. Rhomadhona, "Aplikasi Pendeteksi Kualitas Air Menggunakan," Core IT, vol. 5, no. 1, pp. 13$18,2019$.

[13] F.- Puspasari, I. Fahrurrozi, T. P. Satya, G. Setyawan, M. R. Al Fauzan, and E. M. D. Admoko, "Sensor Ultrasonik HCSR-04 Berbasis Arduino Due Untuk Sistem Monitoring Ketinggian," J. Fis. dan Apl., vol. 15, no. 2, p. 36, 2019, doi: 10.12962/j24604682.v15i2.4393.

[14] E. E. Barus, A. C. Louk, and R. K. Pinggak, "Otomatisasi Sistem Kontrol pH dan Informasi Suhu pada Akuarium menggunakan Arduino Uno dan Raspberry PI 3," J. Fis. Fis. Sains dan Apl., vol. 3, no. 2, pp. 117-125, 2018, doi: 10.35508/fisa.v3i2.612.

[15] M. Imam, E. Apriaskar, and Djuniadi, "Pengendalian Suhu Air Menggunakan Sensor Suhu DS18B20," J. J-Ensitec, vol. 06, no. 01, pp. 347-352, 2019.

[16] Y. Efendi, "Internet Of Things (Iot) Sistem Pengendalian Lampu Menggunakan Raspberry Pi Berbasis Mobile," J. Ilm. Ilmu Komput., vol. 4, no. 2, pp. 21-27, 2018, doi: 10.35329/jiik.v4i2.41.

[17] P. Handoko, H. Hermawan, and M. Nasucha, 
"Pengembangan Sistem Kendali Alat Elektronika Menggunakan Mikrokontroler Arduino Uno R3 dan Ethernet Shield dengan Antarmuka Berbasis Android," Din. Rekayasa, vol. 14, no. 2, pp. 92-103, 2018, doi: 10.20884/1.dr.2018.14.2.191.

[18] L. Birt, S. Scott, D. Cavers, C. Campbell, and F. Walter, "Member Checking: A Tool to Enhance
Trustworthiness or Merely a Nod to Validation?," Qual. Health Res., vol. 26, no. 13, pp. 1802-1811, 2016, doi: $10.1177 / 1049732316654870$.

[19] V. Clarke and V. Braun, "Thematic analysis," J. Posit. Psychol., vol. 12, no. 3, pp. 297-298, 2017, doi: 10.1080/17439760.2016.1262613. 